\title{
ANALISIS FAKTOR-FAKTOR KESUKSESAN PENERAPAN ENTERPRISE RESOURCE PLANNING (ERP) PADA PERUSAHAAN PENGGUNA ERP WILAYAH BALI
}

\section{SUCCESS FACTORS ANALYSIS OF THE APPLICATION OF "ENTERPRISE RESOURCE PLANNING" (ERP) IN ERP USER COMPANIES IN BALI REGION}

\author{
Putu Purnama Dewi ${ }^{1}$, Ni Luh Putu Asriani ${ }^{2}$ \\ ${ }^{123}$ Universitas Pendidikan Nasional Denpasar \\ 1purnamadewi@undiknas.ac.id, ${ }^{2}$ putuasriani14@gmail.com
}

\begin{abstract}
Abstrak
Penelitian ini bertujuan untuk menganalisis faktor-faktor kesuksesan penerapan Enterprise Resource Planning (ERP) dengan menggunakan variabel dependen yaitu kualitas informasi, kualitas sistem, kepuasan pengguna dan kompetensi sumber daya manusia (SDM) terhadap variabel independen yaitu penggunaan sistem ERP. Penelitian ini dilakukan pada perusahaan pengguna ERP wilayah Bali. Adapun perusahaan tersebut adalah PT PLN (Persero) UP2D Bali, PT Pertamina Cab. Bali, PT Telkomsel Cab. Bali dan PT. Bali Ocean Magic dengan menggunakan karyawan bagian akuntansi sebagai responden. Jumlah responden dalam penelitian ini adalah 54 orang. Teknik analisis data yang digunakan adalah teknik analisis regresi linear berganda yang dioperasikan melalui program SPSS versi 20.0. Hasil dari analisis menunjukkan bahwa kualitas informasi berpengaruh negatif terhadap penggunaan sistem ERP. Kualitas informasi memiliki nilai koefisien sebesar 0,016 dengan nilai signifikasi sebesar $0,370>0,5$ sehingga H1 ditolak. Sementara kualitas sistem memiliki nilai koefisien sebesar 0,265 dengan nilai sig. sebesar $0,000<0,5$, kepuasan pengguna memiliki nilai koefisien sebesar 0,187 dengan nilai sig. 0,011<0,05 dan kompetensi SDM memiliki nilai koefisien sebesar 0,133 dengan nilai sig. $0,026<0,05$ sehingga $\mathrm{H} 2, \mathrm{H} 3$ dan $\mathrm{h} 4$ diterima dan dapat dikatakan berpengaruh positif terhadap penggunaan sistem ERP.
\end{abstract}

Kata Kunci: Kualitas Informasi, Kualitas Sistem, Kompetensi Sumber Daya Manusia, Enterprise Resource Planning (ERP)

\begin{abstract}
This study aims to analyze the success factors of the application of Enterprise Resource Planning (ERP) by using dependent variables namely information quality, system quality, user satisfaction, and human resource competency (HR) on independent variables, namely the use of ERP system. This research was conducted on ERP user companies in the Bali region. Those companies are PT PLN (Persero) UP2D Bali, PT Pertamina (Bali branch), PT Telkomsel (Bali branch), and PT. Bali Ocean Magic by using the accounting employees as the respondents. The number of respondents in this study was 54 people. The data analysis technique used is multiple linear regression analysis technique which was operated through the SPSS version 20.0 program. The results of the analysis show that the quality of information has a negative effect on the use of the ERP system. Information quality has a coefficient of 0.016 with a significance value of $0.370>0.5$ and thus $H 1$ is rejected. While the quality of the system has a coefficient of 0.265 with a sig. value of $0,000<0,5$, user satisfaction has a coefficient of 0.187 with a sig. value of $0.011<0.05$ and HR competency has a coefficient of 0.133 with sig. Value of $0,026<0.05$ and thus $\mathrm{H2}, \mathrm{H3}$ and $\mathrm{H} 4$ are accepted and can be said that it has a positive effect on the use of the ERP system.
\end{abstract}

Keywords: Information quality, system quality, Human Resource competency, Enterprise Resource Planning $(E R P)$ 


\section{PENDAHULUAN}

Kemajuan yang pesat dalam teknologi telah membuka kemungkinan untuk menggunakan informasi akuntansi dari sudut pandang strategis, ini dikarenakan perusahaan membutuhkan informasi ini untuk dapat berhadapan dengan tingkat yang lebih tinggi dari ketidakpastian pasar yang semakin tidak kompetitif. Sampai saat ini sistem informasi akuntansi sudah banyak ditawarkan dengan tujuan untuk membantu pengelolaan dan pengendalian topik yang terkait dengan bidang ekonomi dan keuangan secara tepat (Urquia et al.,2010).

Perkembangan teknologi informasi (TI) telah memberikan wadah bagi manajemen untuk mengelola bisnis dan pembuatan keputusannya. Sistem informasi yang didukung TI dapat memberikan nilai tambah bagi organisasi jika dirancang menjadi sistem informasi yang efektif, sistem informasi yang menandakan bahwa sistem tersebut sukses. Namun, pengukuran atau penilaian kualitas suatu sistem informasi yang efektif sulit dilakukan secara langsung seperti pengukuran biaya-manfaat (Laudon dan Laudon, 2000). Kesulitan penilaian kesuksesan dan keefektifan sistem informasi secara langsung membuat banyak peneliti mengembangkan model untuk menilai kesuksesan sistem informasi. (Romney dan Steinbart,2009) mengungkapkan bahwa "implementasi sistem informasi akuntansi berbasis teknologi di perusahaan dapat memberikan nilai tambah pemakai yang akhirnya berdampak positif pada peningkatan kinerja individual.” Bagi perusahaan, produktivitas kerja merupakan tuntutan utama agar dapat menjaga kelangsungan hidup atau operasionalnya. Peningkatan kinerja individu tidak akan tercapai jika penerapan Sistem Informasi Akuntansi (SIA) yang tidak sesuai dengan kebutuhan pengguna. Sistem informasi akuntansi dikatakan efektif jika informasi yang dihasilkan oleh sistem tersebut dapat melayani kebutuhan pengguna sistem (Sajady,2008).

Teknologi informasi diaplikasikan dalam perusahaan untuk meningkatkan produktivitas dan membantu pencapaian kualitas, standar waktu, dan kepuasan baik bagi konsumen maupun karyawan, dimana dalam dunia bisnis hal ini diwujudkan dalam serangkaian sistem yang terdiri atas sistem informasi dan infrastruktur pendukungnya. Salah satu solusi yang menjadi primadona bisnis saat ini adalah suatu sistem untuk mengelola sumber daya perusahaan secara keseluruhan atau yang biasa dikenal dengan istilah Enterprise Resource Planning (ERP). ERP mempunyai kemampuan untuk mengintegrasikan semua proses yang ada dalam area fungsional perusahaan, misalnya antar departemen, maupun antar lokasi yang berbeda. Dengan adanya integrasi sistem ini data yang sebelumnya didapat dari sistem yang berbeda-beda akan diintegrasikan menjadi sistem tunggal dengan format yang standar. Dengan demikian tidak ada lagi perbedaan proses yang terjadi antar fungsi, antar departemen, maupun antar lokasi yang berbeda.

Software ERP yang banyak digunakan perusahan yakni SAP dan ORACLE. Penerapan implementasi ERP sendiri sangat rumit karena biaya yang dibutuhkan sangat besar dan kurun waktu tidak sebentar (Rahmawati 2008).

Kegagalan sistem ERP dapat terjadi dikarenakan kompleksitas ketika implementasi, adanya masalah integrasi, kekurangan dana, ketidaksesuaian penjadwalan proyek, dan resistensi pengguna terhadap perubahan (Marinos dan Zahir, 2003). Pada umumnya penerapan implementasi ERP membutuhkan presentase biaya sekitar $0,82 \%$ dari pendapatan perusahaan sedangkan pada perusahaan kecil dapat mencapai 13,65\% dari pendapatannya yang dinyatakan oleh (Mabert, 2000). Di Indonesia terdapat banyak kasus dimana implementasi ERP memakan waktu jauh lebih lama dari praktik umumnya yang hanya memerlukan waktu 6 hingga 12 bulan (Fitrah, 2010), namun banyak juga perusahaan yang secara umum dapat dikatakan berhasil. Sehingga perusahaan mampu meningkatkan kepatuhan dan tata kelola (good corporate governance) dan meningkatkan citra perusahaan (Herdian 2014).

Kemampuan untuk mengintegrasikan proses bisnis di suatu perusahaan ini yang kemudian menjadi daya tarik tersendiri bagi pihak manajemen untuk menerapkan ERP. Inilah yang selanjutnya melatarbelakangi banyak perusahaan di dunia, termasuk di Indonesia beramai-ramai untuk menerapkan ERP di perusahaannya. Saat ini sudah ada beberapa perusahaan yang menerapkan sistem ERP ini di Indonesia, salah satunya adalah di wilayah Bali. Beberapa perusahaan ini merupakan cabang dari perusahaan induk yang berlokasi di DKI Jakarta. Adapun perusahaan-perusahaan pengguna ERP yang penulis teliti menggunakan sistem ERP di wilayah Bali adalah sebagai berikut: 
1. PT Telkomsel Cab.Denpasar

2. PT Pertamina Cab.Denpasar

3. PT PLN (Persero) UP2DBali

4. PT Bali OceanMagic

Saat ini sistem ERP merupakan salah satu solusi bisnis yang terintegrasi bagi perusahaan sebagai sarana bersaing yang kuat dengan kompetitor. Sistem ERP dapat mengintegrasikan fungsifungsi bisnis ke dalam proses bisnis yang unified dan terintegrasi. Sayangnya, kebanyakan implementasi sistem ERP tidak dapat memenuhi harapan. Banyak perusahaan yang sudah mengeluarkan biaya besar untuk implementasi sistem ini namun tidak berhasil memperoleh manfaat dan keuntungan dari implementasi sistem ERP ini. Menurut beberapa penelitian tentang sistem ERP, kegagalan biasanya disebabkan bukan terletak pada kesalahan instalasi software tapi sebagian besar disebabkan oleh kesalahan yang dilakukan perusahaan untuk menentukan sistem yang tepat untuk menyelesaikan masalah bisnis dan kebutuhan perusahaan tersebut. Tidak hanya itu, keengganan dan penolakan dari user (pengguna) dan ketidakmampuan perusahaan-perusahaan untuk menentukan perubahan pada desain dan struktur organisasi sesuai dengan manfaat teknologi yang dipilih menyebabkan tidak didapatnya manfaat dan keuntungan dari sistem ERP ini. Penolakan user dalam menggunakan sistem baru (sistem ERP) merupakan salah satu alasan kegagalan implementasi yang seharusnya diperhatikan oleh perusahaan. Kurangnya penerimaan oleh user tersebut menyebabkan user hanya sekedar terpaksa menggunakan dan tanpa diimbangi dengan penggunaan yang handal pada sistem ERP.

Karena banyaknya kegagalan implementasi sistem ERP yang dialami oleh perusahaan, maka dari itu peneliti ingin mengetahui apa saja faktor-faktor yang menjadi kesuksesan penerapan sistem Enterprise Resource Planning (ERP) ini. Keunggulan dari penelitian ini adalah memasukkan variabel baru yaitu Kompetensi Sumber Daya Manusia (SDM) untuk mengetahui apakah ada pengaruh yang signifikan dengan penggunaan sistem ERP.

Kualitas informasi adalah salah satu faktor kesuksesan penggunaan sistem ERP. Hal ini didukung oleh hasil beberapa penelitian, yaitu: DeLone and McLean (1992), Seddon and Kiew (1996), Seddon (1997), dan Petter et al. (2008) dengan melakukan penelitian untuk melihat adanya pengaruh antara kualitas informasi dengan penggunaan sistem. Hasil penelitian menunjukkan adanya pengaruh positif antara dua variabel tersebut. Jika informasi yang dihasilkan semakin akurat, tepat waktu, dan memiliki reliabilitas yang baik, maka penggunaan sistem ERP akan semakin meningkat. Berdasarkan penjelasan di atas, maka hipotesis kedua dapat dirumuskan sebagai berikut:

\section{H1: Kualitas Informasi berpengaruh positif pada Kesuksesan Penggunaan Sistem ERP.}

Kualitas sistem merupakan karakteristik dari informasi yang melekat mengenai sistem itu sendiri (DeLone and McLean, 1992). Hasil dari penelitian DeLone and McLean (1992) yang didukung oleh beberapa peneliti selanjutnya, yaitu Seddon and Kiew (1996), Seddon (1997), dan Petter et al. (2008), menunjukkan adanya pengaruh kualitas informasi terhadap penggunaan sistem. Penelitian Davis (1989) mendefinisikan kualitas sistem informasi sebagai perceived ease of use dengan menggunakan model TAM untuk menunjukkan bahwa kualitas sistem informasi memiliki pengaruh terhadap penggunaan sistem. Berdasarkan penjelasan di atas, maka diajukan hipotesis:

\section{H2: Kualitas Sistem berpengaruh postif pada Kesuksesan Penggunaan SistemERP.}

Model kesuksesan sistem informasi yang dikembangkan DeLone and McLean (1992) dan Seddon (1997) menguji pengaruh kepuasan pengguna terhadap penggunaan system didukung oleh hasil penelitian selanjutnya, diantaranya: Seddon and Kiew (1996), Hsieh and Wang (2007), dan Petter et al. (2008). Berdasarkan penjelasan di atas, maka diajukan hipotesis sebagai berikut: H3: Kepuasan Pengguna berpengaruh positif pada Kesuksesan Penggunaan Sistem ERP.

Kompetensi SDM menjadi faktor penentu yang perlu dicermati dalam kesuksesan penggunaan sistem ERP. Kompetensi SDM dapat dilihat dari pendidikan dan pelatihan yang mengacu pada proses persiapan bagi karyawan dan manajemen melalui penjelasan-penjelasan 
tentang logika dan keseluruhan konsep sistem ERP. sehingga orang akan dapat memahami dengan lebih baik bagaimana pekerjaan berhubungan dengan area fungsional lain di dalam perusahaan. Dengan dimilikinya SDM berkompeten yang memadai bagi para karyawan sebagai pemakai/user sistem ERP, maka dapat memudahkan pengguna dalam memahami penggunaan sistem ERP. Oleh karena itu, diajukan hipotesis sebagai berikut:

\section{H4: Kompetensi SDM berpengaruh positif pada Kesuksesan Penggunaan Sistem ERP.}

\section{METODE}

Lokasi yang digunakan pada penelitian ini dilakukan di Perusahaan pengguna sistem Enterprise Resource Planning (ERP) wilayah Bali. Adapun perusahaan yang menjadi objek penelitian ini adalah: PT Telkomsel Cab. Denpasar, PT Pertamina Cab. Denpasar, PT PLN (Persero) UP2D Bali, dan PT Bali Ocean Magic.

Populasi dalam penelitian ini merupakan jumlah karyawan bagian akuntansi pada perusahaan pengguna ERP yang berjumlah 54 orang. Sampel pada penelitian ini adalah sampel jenuh. Karena jumlah populasi yang diteliti berjumlah 54 orang, maka sampel penelitian ini juga 54 orang. Sehingga penelitian ini merupakan penelitian populasi atau sensus.

Teknik pengumpulan data pada penelitian ini dengan menggunakan kuesioner dengan pernyataan tertutup dan jawaban dengan pilihan modifikasi skala likert. Teknik analisis data yang digunakan yaitu analisis regresi linear berganda. Teknik analisis data analisis regresi linear berganda diawali dengan melakukan uji asumsi klasik yaitu uji normalitas, uji heteroskedastisitas, dan uji multikolinearitas, dan terakhir yaitu melakukan uji hipotesis yang dikerjakan melalui program SPSS versi20.0.

Sedangkan model penelitiannya adalah sebagai berikut:

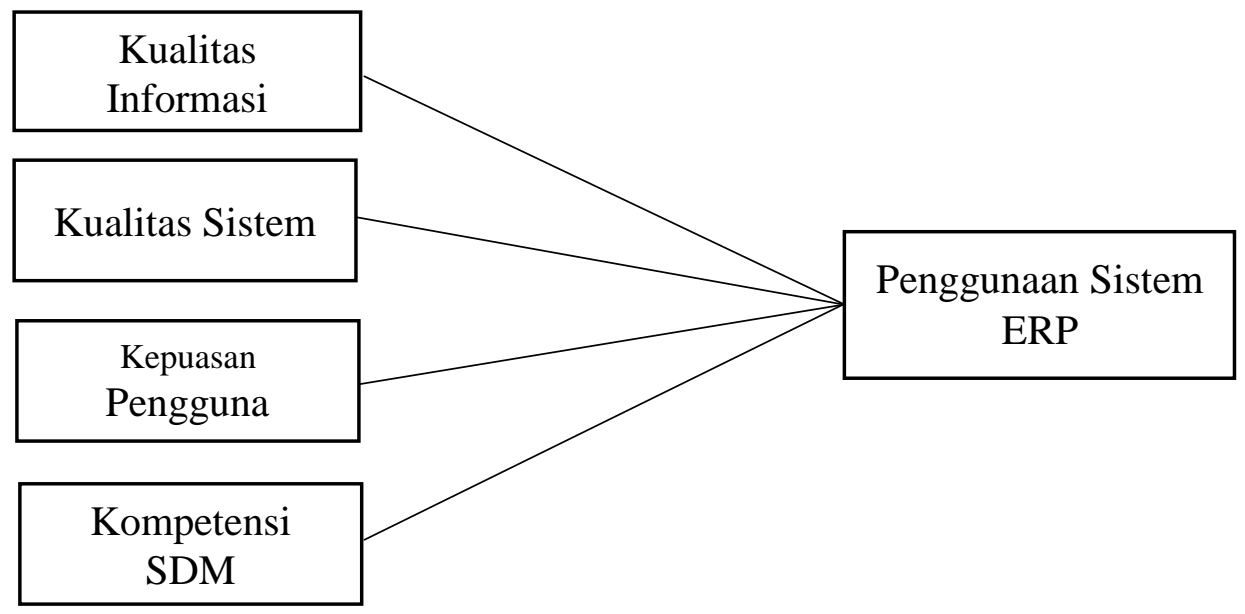

Gambar.1 Metode Penelitian

Analisis data yang digunakan adalah Analisis Regresi Berganda dengan persamaan:

$$
\mathrm{Y}=\mathrm{a}+\mathrm{b} 1 \mathrm{X} 1+\mathrm{b} 2 \mathrm{X} 2+\mathrm{b} 3 \mathrm{X} 3+\mathrm{b} 4 \mathrm{X} 4+\mathrm{e} .
$$

\section{HASIL DAN PEMBAHASAN}

\section{Kriteria Responden}

Berdasarkan data yang telah dikumpulkan, dari 54 responden yang diperoleh memiliki karakteristik yang meliputi jumlah responden berusia $20-25$ tahun sebanyak 23 responden, $26-35$ tahun sebanyak 22 responden, 36 - 45 tahun sebanyak 8 responden dan $>45$ tahun sebanyak 1 responden. Jumlah responden yang lama bekerja $1-12$ bulan sebanyak 6 responden, $>1-5$ tahun sebanyak 16 responden, dan $>5$ tahun sebanyak 32 responden. Berdasarkan jenis kelamin, terdapat 28 responden yang berjenis kelamin laki-laki, dan 26 responden yang berjenis kelamin perempuan. 


\section{Uji Asumsi Klasik Uji Normalitas}

Tabel 1. Hasil Uji Normalitas

One-Sample Kolmogorov-Smirnov Tes

\begin{tabular}{|c|c|c|}
\hline & & $\begin{array}{l}\text { Unstandardiz } \\
\text { ed Residual }\end{array}$ \\
\hline $\bar{N}$ & & 54 \\
\hline \multirow[t]{2}{*}{ Normal Parameters ${ }^{a, b}$} & Mean & $O E-7$ \\
\hline & Std. Deviation & 1,71910910 \\
\hline \multirow{3}{*}{ Most Extreme Differences } & Absolute & , 102 \\
\hline & Positive & 102 \\
\hline & Negative &,- 070 \\
\hline Kolmogorov-Smirnov Z & & .750 \\
\hline Asymp. Sig. (2-tailed) & & 628 \\
\hline
\end{tabular}

a. Test distribution is Normal.

b. Calculated from data

Sumber: SPSS versi $20.0(2018)$

Pada tabel 1 diatas menunjukkan bahwa nilai Kolmogorov-Smirnov Z sebesar 0,750 sedangkan nilai Asymp. Sig (2-tailed) sebesar 0,628. Hasil tersebut mengindikasikan bahwa model persamaan regresi berdistribusi normal karena nilai Asymp. Sig (2-tailed) 0,628 lebih besar dari alpha 0,05.

\section{Uji Multikolinieritas}

Tabel 2. Hasil Uji Multikolinieritas

Coefficients $^{\mathrm{a}}$

\begin{tabular}{|c|c|c|c|c|c|c|c|c|}
\hline \multirow[b]{2}{*}{ Modt } & & \multicolumn{2}{|c|}{ Unstandardized Coefficients } & \multirow{2}{*}{$\begin{array}{c}\begin{array}{c}\text { Standardized } \\
\text { Coefficients }\end{array} \\
\text { Beta }\end{array}$} & \multirow[b]{2}{*}{ t } & \multirow[b]{2}{*}{ Sig. } & \multicolumn{2}{|c|}{ Collinearity Statistics } \\
\hline & & B & Std. Error & & & & Tolerance & VIF \\
\hline \multirow[t]{5}{*}{1} & (Constant) & $-4,180$ & 3,246 & & $-1,288$ & 204 & & \\
\hline & Kualitas Informasi & .016 & .045 & .039 & .370 &, 713 & .929 & 1,077 \\
\hline & Kualitas Sistem & ,265 &, 064 & .461 & 4,119 & ,000 & 809 & 1,236 \\
\hline & Kepuasan Pengguna & 187 & 071 &, 272 & 2,626 &, 011 & 947 & 1,056 \\
\hline & Kompetensi SDM & 133 &, 058 &, 255 & 2,302 & .026 & 826 & 1,211 \\
\hline
\end{tabular}

a. Dependent Variable: Penggunaan Sistem ERP

Sumber: SPSS versi $20.0(2018)$

Pada tabel diatas dapat dilihat bahwa Tabel 2 di atas menunjukkan bahwa nilai tolerance dari variabel bebas (independen) $>0,10$ dan nilai $\mathrm{VIF} \leq 10$, maka dapat disimpulkan bahwa tidak terjadi gejala multikolinearitas antara variabel bebas dalam model regresi.

\section{Uji Heteroskedastisitas}

Tabel 3. Hasil Uji Heteroskedastisitas

Coefficients $^{a}$

\begin{tabular}{|c|c|c|c|c|c|c|}
\hline \multirow[b]{2}{*}{ Mode } & & \multicolumn{2}{|c|}{ Unstandardized Coefficients } & \multirow{2}{*}{$\begin{array}{c}\begin{array}{c}\text { Standardized } \\
\text { Coefficients }\end{array} \\
\text { Beta } \\
\end{array}$} & \multirow[b]{2}{*}{$t$} & \multirow[b]{2}{*}{ Sig. } \\
\hline & & B & Std. Error & & & \\
\hline \multirow[t]{5}{*}{1} & (Constant) & 2,722 & 1,949 & & 1,396 & 169 \\
\hline & Kualitas Informasi &, 029 & 027 &, 153 & 1,079 & 286 \\
\hline & Kualitas Sistem &, 028 &, 039 & 111 &, 729 & 469 \\
\hline & Kepuasan Pengguna &,- 052 &, 043 &,- 170 & $-1,214$ & 231 \\
\hline & Kompetensi SDM &,- 042 &, 035 &,- 180 & $-1,197$ & 237 \\
\hline
\end{tabular}

a. Dependent Variable: abres

Sumber: SPSS versi $20.0(2018)$

Berdasarkan tabel 3 di atas menunjukkan bahwa semua variabel bebas memiliki nilai signifikansi yaitu: 0,$286 ; 0,469 ; 0,231$ dan 0,237 menunjukkan bahwa nilai signifikansinya $>0,05$ 
maka dapat disimpulkan bahwa tidak terdapat gejala heteroskedastisitas.

\section{Analisis Regresi Linear Berganda}

Tabel 4. Hasil Analisis Regresi Berganda

\begin{tabular}{|c|c|c|c|c|c|c|}
\hline \multicolumn{7}{|c|}{ Coefficients $^{a}$} \\
\hline \multirow[b]{2}{*}{ Mod } & & \multicolumn{2}{|c|}{ Unstandardized Coefficients } & \multirow{2}{*}{$\begin{array}{c}\text { Standardized } \\
\text { Coefficients } \\
\text { Beta }\end{array}$} & \multirow[b]{2}{*}{$t$} & \multirow[b]{2}{*}{ Sig. } \\
\hline & & B & Std. Error & & & \\
\hline \multirow[t]{5}{*}{1} & (Constant) & $-4,180$ & 3,246 & & $-1,288$ & 204 \\
\hline & Kualitas Informasi & 016 & .045 &, 039 &, 370 &, 713 \\
\hline & Kualitas Sistem & .265 &, 064 & .461 & 4,119 &, 000 \\
\hline & Kepuasan Pengguna & 187 & 071 &, 272 & 2,626 & 011 \\
\hline & Kompetensi SDM & 133 &, 058 & ,255 & 2,302 & ,026 \\
\hline
\end{tabular}

Berdasarkan Tabel 4 diperoleh suatu persamaan regrei berganda sebagai berikut:

$$
\begin{gathered}
Y=a+b 1 X 1+b 2 X 2+b 3 X 3+b 4 X 4 \\
Y=-4,180+0,016 X 1+0,265 X 2+0,187 X 3+0,133 X 4
\end{gathered}
$$

1) Koefisien konstanta sebesar $-4,180$, artinya bila kualitas informasi (X1), kualitas sistem (X2), kepuasan pengguna (X3) dan kompetensi SDM (X4) sama dengan nol maka penggunaan sistem ERP (Y) adalah sebesar-4,180.

2) Koefisien regresi kualitas informasi (X1) sebesar 0,016 dengan nilai signifikan 0,713 lebih besar dari 0,05 hal ini berarti kualitas informasi (X1) tidak berpengaruh terhadap penggunaan sistemERP.

3) Koefisien regresi kualitas sistem (X2) sebesar 0,265 dengan nilai signifikan 0,000 lebih kecil dari 0,05 hal ini berarti bila kualitas sistem (X2) bertambah satu satuan, maka penggunaan sistem ERP akan bertambah 0,265 dengan asumsi variabel lainkonstan.

4) Koefisien regresi kepuasan pengguna (X3) sebesar 0.187 dengan nilai signifikan 0,011 lebih kecil dari 0,05 hal ini berarti bila kepuasan pengguna (X3) bertambah satu satuan, maka penggunaan sistem ERP akan bertambah 0,187 dengan asumsi variabel lainkonstan.

5) Koefisien regresi kompetensi SDM (X4) sebesar 0,133 dengan nilai signifikan 0,026 lebih kecil dari 0,05 hal ini berarti bila kompetensi SDM (X4) bertambah satu satuan, maka penggunaan sistem ERP akan bertambah 0,133 dengan asumsi variabel lainkonstan.

\section{Uji T (Uji SignifikansiParsial)}

Tabel 5 Hasil Uji t

\begin{tabular}{|c|c|c|c|c|c|c|}
\hline \multirow{2}{*}{\multicolumn{2}{|c|}{ Model }} & \multicolumn{2}{|c|}{ Unstandardized Coefficients } & \multirow{2}{*}{$\begin{array}{c}\text { Standardized } \\
\text { Coefficients }\end{array}$} & \multirow[b]{2}{*}{$\mathrm{t}$} & \multirow[b]{2}{*}{ Sig. } \\
\hline & & $B$ & Std. Error & & & \\
\hline \multirow[t]{5}{*}{1} & (Constant) & $-4,180$ & 3,246 & & $-1,288$ & 204 \\
\hline & Kualitas Informasi &, 016 &, 045 &, 039 &, 370 &, 713 \\
\hline & Kualitas Sistem &, 265 &, 064 & .461 & 4,119 &, 000 \\
\hline & Kepuasan Pengguna & 187 &, 071 &, 272 & 2,626 &, 011 \\
\hline & Kompetensi SDM &, 133 &, 058 & 255 & 2,302 &, 026 \\
\hline
\end{tabular}

Coefficients $^{a}$

a. Dependent Variable: Penggunaan Sistem ERP

Sumber: SPSS versi 20.0 (2018) 
Berdasarkan Tabel 5, dapat dijelaskan bahwa:

1. Pengaruh kualitas informasi terhadap kesuksesan penggunaan sistem ERP Variabel kualitas informasi (X1) menunjukkan nilai koefisien regresi sebesar 0,016, nilai thitung sebesar 0,370 dengan nilai signifikansi 0,713 dimana nilai tersebut lebih besar dari 0,05 sehingga $\mathrm{H} 1$ ditolak. Ini berati bahwa kualitas informasi (X1) tidak berpengaruh terhadap kesuksesan penggunaan sistem ERP (Y).

2. Pengaruh kualitas sistem terhadap kesuksesan penggunaan sistem ERP Variabel kualitas sistem (X2) menunjukkan nilai koefisien regresi sebesar 0,265, nilai thitung sebesar 4,119 dengan nilai signifikansi 0,000 dimana nilai tersebut lebih kecil dari 0,05 sehingga $\mathrm{H} 2$ diterima. Ini berati bahwa kualitas sistem (X2) berpengaruh positif terhadap kesuksesan penggunaan sistem ERP (Y).Pengaruh kepuasan pengguna terhadap kesuksesan penggunaan sistem ERP Variabel kepuasan pengguna (X3) menunjukkan nilai koefisien regresi sebesar 0,187 , nilai thitung sebesar 2,626 dengan nilai signifikansi 0,011 dimana nilai tersebut lebih kecil dari 0,05 sehingga $\mathrm{H} 3$ diterima. Ini berati bahwa kepuasan pengguna (X3) berpengaruh positif terhadap kesuksesan penggunaan sistem $\operatorname{ERP}(\mathrm{Y})$.

3. Pengaruh kompetensi SDM terhadap penggunaan sistem ERP

Variabel kompetensi SDM (X4) menunjukkan nilai koefisien regresi sebesar 0,133, nilai thitung sebesar 2,302 dengan nilai signifikansi 0,026 dimana nilai tersebut lebih kecil dari 0,05 sehingga $\mathrm{H} 4$ diterima. Ini berati bahwa kompetensi SDM (X3) berpengaruh positif terhadap kesuksesan penggunaan sistem ERP (Y).

\section{Pembahasan}

\section{Pengaruh kualitas informasi terhadap kesuksesan penggunaan sistem ERP}

Hipotesis pertama menyatakan bahwa kualitas informasi berpengaruh positif terhadap kesuksesan penggunaan sistem ERP. Berdasarkan hasil uji regresi linear berganda menunjukkan bahwa kualitas informasi memiliki nilai koefisien sebesar 0,016 dengan nilai signifikansi sebesar $0,370>0,05$ sehingga $\mathrm{H} 1$ ditolak. Hal ini berarti bahwa kualitas informasi tidak berpengaruh terhadap kesuksesan penggunaan sistem ERP. Hal tersebut mengindikasikan bahwa kualitas informasi tidak cukup mampu untukmempengaruhi kesuksesan penggunaan sistem ERP. Hal ini dilihat dari adanya faktor kualitas informasi yang dihasilkan sistem tersebut tidak memiliki tingkat akurasi yang baik, tidak tepat waktu, dan tidak memiliki reliabilitas yang baik, maka penggunaan sistem ERP belum mampu untuk mempengaruhinya. Disamping itu kesenjangan informasi yang terjadi antara pihak pengguna dan sistem dirasa menjadi faktor yang dapat memicu kurang suksesnya penggunaan sistem informasi pada suatuperusahaan.

Hasil penelitian ini sejalan dengan penelitian terdahulu yang dilakukan oleh Akram, Animah dan Prayitno Basuki (2017) menunjukkan hasil bahwa kualitas informasi tidak berpengaruh terhadap kesuksesan penggunaan sistem ERP.

\section{Pengaruh kualitas sistem terhadap kesuksesan penggunaan sistem ERP}

Hipotesis kedua menyatakan bahwa kualitas sistem berpengaruh positif terhadap kesuksesan penggunaan sistem ERP. Berdasarkan hasil uji regresi linear berganda menunjukkan bahwa kualitas sistem memiliki nilai koefisien sebesar 0,265 dengan nilai signifikansi sebesar 0,000< 0,05 sehingga $\mathrm{H} 2$ diterima. Hal inii berarti bahwa kualitas sistem berpengaruh positif terhadap kesuksesan penggunaan sistem ERP. Kualitas sistem (system quality) digunakan untuk mengukur kualitas sistem tekonologi informasinya sendiri. Secara parsial,kualitas sistem berpengaruh signifikan terhadap kesuksesan penggunaan sistem ERP. Hal ini membuktikan bahwa pengukuran tingkat kesuksesan kualitas sistem informasii sudah baik bahkan dapat mempengaruhi kesuksesan penggunaan sistem ERP, karena sistem yang digunakan dapat menunjang kebutuhan pekerjaan pengguna. Suatu sistem yang baik adalah apabila penggunaannya dapat berinteraksi dengan baik oleh pengguna dan dapat mengantarkan pengguna dalam mencapai suatu tujuan yang diharapkan. Disamping itu, dapat dilihat dari kemudahan sistem untuk dipelajari oleh orang yang pertama kali menggunakan dan kecanggihan sistem tersebut membuat pengguna mampu menggunakannya dengan baik, juga mampu meningkatkan produktivitas kinerja. Hal tersebut akan memberikan 
dampak yang positif terhadap kesuksesan penggunaan sistem ERP di suatu perusahaan.

Hasil penelitian ini sejalan dengan penelitian terdahulu yang dilakukan oleh Brigida Arie Minartiningtyas (2011) yang menemukan hasil bahwa kualitas sistem berpengaruh positif terhadap kesuksesan penggunaan sisteminformasi.

\section{Pengaruh kepuasan pengguna terhadap penggunaan sistem ERP}

Hipotesis ketiga menyatakan bahwa kepuasan pengguna berpengaruh positif terhadap kesuksesan penggunaan sistem ERP. Berdasarkan hasil uji regresi linear berganda menunjukkan bahwa kepuasan pengguna memiliki nilai koefisien sebesar 0,187 dengan nilai signifikansi sebesar $0,011<0,05$ sehingga $\mathrm{H} 3$ diterima. Hal ini berarti bahwa kepuasan pengguna berpengaruh positif terhadap kesuksesan penggunaan sistem ERP. Hal ini mengindikasikan bahwa semakin tinggi kepuasan pengguna maka kesuksesan penggunaan sistem ERP akan semakin meningkat. Dampak pemakaian suatu sistem informasi terhadap individu pengguna (individual impact) didefinisikan sebagai tingkat dimana seseorang percaya bahwa dengan menggunakan sistem tertentu dapat meningkatkan kinerjanya. Sementara itu, antara dampak kepuasan penggunaan sistem informasi terhadap kesuksesan penggunaan sistem ERP dengan tingkat kepuasan pemakai (user satisfaction) memiliki hubungan yang sifatnya timbal balik (reciprocal), sehingga akan mempengaruhi tingkat kesuksesan penggunaan sistem ERP.

Hasil penelitian ini sejalan dengan penelitian terdahulu yang dilakukan oleh Akram, Animah dan Prayitno Basuki (2017) menunjukkan hasil bahwa kepuasan pengguna berpengaruh positif terhadap kesuksesan penggunaan sistem ERP.

\section{Pengaruh kompetensi sumber daya manusia (SDM) terhadap penggunaan sistem ERP}

Hipotesis ketiga menyatakan bahwa kompetensi SDM berpengaruh positif terhadap kesuksesan penggunaan sistem ERP. Berdasarkan hasil uji regresi linear berganda menunjukkan bahwa kompetensi SDM memiliki nilai koefisien sebesar 0,133 dengan nilai signifikansi sebesar $0,026<0,05$ sehingga H4 diterima. Hal ini berarti bahwa kompetensi SDM berpengaruh positif terhadap kesuksesan penggunaan sistem ERP. Hal ini mengindikasikan bahwa semakin tinggi kompetensi SDM maka kesuksesan penggunaan sistem ERP akan semakin meningkat. Kompetensi SDM menjadi faktor penentu yang perlu dicermati dalam kesuksesan penggunaan sistem ERP. Kompetensi SDM dapat dilihat dari pendidikan dan pelatihan yang mengacu pada proses persiapan bagi karyawan dan manajemen melalui penjelasan-penjelasan tentang logika dan keseluruhan konsep sistem ERP. sehingga orang akan dapat memahami dengan lebih baik bagaimana pekerjaan berhubungan dengan area fungsional lain di dalam perusahaan. Dengan dimilikinya SDM berkompeten yang memadai bagi para karyawan sebagai pemakai/user sistem ERP, maka dapat memudahkan pengguna dalam memahami penggunaan sistem ERP.

Hasil penelitian ini sejalan dengan penelitian terdahulu yang dilakukan oleh Akram, Animah dan Prayitno Basuki (2017) menunjukkan hasil bahwa kompetensi SDM berpengaruh positif terhadap kesuksesan penggunaan sistem ERP.

\section{KESIMPULAN}

Hasil penelitian yang telah dilakukan dapat disimpulkan sebagai berikut:

1. Kualitas informasi tidak berpengaruh terhadap kesuksesan penggunaan sistem ERP. Hal ini dibuktikan dengan nilai signifikansi yang lebih besar dari level of significant $(0,370>$ $0,05)$ dan nilai koefisien regersi menunjukkan arah hubungan positif sebesar 0,016 .

2. Kualitas sistem berpengaruh positif dan signifikan terhadap kesuksesan penggunaan sistem ERP. Hal ini dibuktikan dengan nilai signifikansi yang lebih kecil dari level of significant $(0,000<0,05)$ dan nilai koefisien regersi menunjukkan arah hubungan positif sebesar0,265.

3. Kepuasan pengguna berpengaruh positif dan signifikan terhadap kesuksesan penggunaan sistem ERP. Hal ini dibuktikan dengan nilai signifikansi yang lebih besar dari level of significant $(0,011<0,05)$ dengan nilai koefisien regresi positif sebesar0,187.

4. Kompetensi SDM berpengaruh positif dan signifikan terhadap kesuksesan penggunaan 
sistem ERP. Hal ini dibuktikan dengan nilai signifikansi yang lebih besar dari level of significant $(0,026<0,05)$ dengan nilai koefisien regresi positif sebesar 0,133 .

\section{DAFTAR PUSTAKA}

Akram, Animah, dan P.B. (2017). Pengaruh Kualitas Sistem Informasi, Kualitas Informasi, Kepuasan Pengguna dan Kompetensi Sumber Daya Manusia Terhadap Penggunaan Sistem ERP (Enterprise Resource Planning) Berbasis TAM (Technology Acceptance Model). Jurnal Magister Manajemen Universitas Mataram, (September), 1-17.

Ernita, H., \& Kusuma, W. A. (2008). Pengembangan Enterprise Resource Planning (ERP). SeminarNasional Informatika (semnasIF 2008). Yogyakarta.

Faridah, E., \& Noviyanti, R. (2017). Pengaruh Kemampuan Personal Pengguna Sistem Informasi. Jurnal Wawasan dan Riset Akuntansi, 4(2), 83-92

Heryana, T., \& Rahman, A. S. (2017). Hubungan Penerapan Enterprise Resource Planning (ERP) Dengan Kualitas Laporan Keuangan. Jurnal Riset Akuntansi dan Keuangan, 1(2).

Lestariningsih, T., Suyanto, M., \& Lutfi, T. E. (2015). Analisis Faktor-Faktor Keberhasilan Implementasi Sistem. Seminar Nasional Teknologi Informasi dan Multimedia.

Marcika, N. d., \& Jati, I. K. (2015). Kemudahan Penggunaan Sistem Sebagai Pemoderasi Pengaruh Efektivitas Sistem Informasi Akuntansi Pada Kinerja. Jurnal Akuntansi Universitas Udayana, 723-737.

Minartiningtyas, B. A. (2011). Model Kesuksesan Penerapan Enterprise Resource Planning Pada Pt Pln (Persero) Distribusi Bali. Thesis.

Morris, J. (2011). The Impact of Enterprise Resource Planning (ERP) System on the Effectiveness of Internal Control over Financial Reporting. Journal of Information System: Spring, 25(1), 129-157.

Mulyadi, Hurriyati , R., \& Gaffar, V. (2015). Faktor Kesuksesan Kritikal Enterprise Resource Planning (ERP) serta Pengaruhnya terhadap Good University Governance (GUG) (Survey pada Pimpinan ST.INTEN). Jurnal Ilmu Manajemen \& Bisnis, 6(2), 24-28.

Napitupulu, D. (2013). Analisa Keberhasilan Sistem Erp. Jakarta, DKI Jakarta. Putra dkk, M. (2018). Implementasi Modul Accounting Dan Finance Menggunakan. e-Proceeding of Engineering, 5 (2), 3214-3221.

Putra, R. E. (2018). Pengaruh Critical Success Dalam Implementasi Enterprise. Akuntabilitas: JurnalIlmu Akuntansi, 9(2), 381-394.

Rahmi, S. (2017). Pengujian Kesuksesan Implementasi ERP (Enterprise Resource. menara ekonomi,3(6).

Rini, W. F., \& Febriani, D. (2017). Dampak Implementasi Enterprise Resource Planning (ERP) atas pengaruh Profitabilitas Terhadap Nilai Perusahaan. Jurnal Aset (Akuntansi Riset), 9(1), $15-28$.

Rektiani, dkk. (2017). Kinerja Keuangan Dan Kapabilitas Perusahaan Sebelum Dan Sesudah. eProceeding of Management, 4(3), 2830-2837.

Rukmiyati, N. M., \& Budiartha, I. K. (2016). Pengaruh Kualitas Sistem Informasi, Kualitas 
Informasi Dan Perceived Usefulnesspada Kepuasan Pengguna Akhir Software akuntansi (Studi Empiris Pada Hotel Berbintang Di Provinsi Bali). E-Jurnal Ekonomi dan Bisnis Universitas Udayana, 5(1),115-142.

Sa'diyah, M. A., \& Mudiantono. (2015). Analisis Kinerja Pemasaran Melalui Keberhasilan. $I S S N, 2(1)$.

Saputro, P. H., Budiyanto, A. D., \& Santoso, A. J. (2015). Model Delone and Mclean untuk Mengukur Kesuksesan. Scientific Journal of Informatics,2(1).

Soetrisno, dkk. (2015). Analisis Metode Kustomisasi Pada Enterprise Resource Planning. ProsidingSNST ke 6. Semarang: Research Gate.

Sehwan. (2016). Revisiting The Relationship Between Information Technology Capability and Firm Performance: Focusing on the Impact of the Adoption of Enterprise Resource Planning Systems. The Journal Of Information Systems. The Korea Assosiation of Information Systems, 25(1), 49-73.

Suhaimi, dkk, N. S. (2016). Impact of Enterprise Resource Planning on Management. Int. Journal of Economics and Management, 93-108.

Wibisono, S. (2005). Enterprise Resource Planning (ERP) Solusi Sistem InformasiTerintegrasi.

Wicaksono, A. (2015). Analisis Dampak Penerapan Sistem Erp. Binus Business Review, 6(1), 2534.

Yulianti, \& Putu. (2011). Analisis Faktor-Faktor Yang Memengaruhi Penerimaan Pengguna Dalam Menggunakan Sistem ERP. Journal of Information Systems, 7(1), 69-75. 